\title{
Article \\ Native Advertising-The Formats and Types of Content Most Demanded by Brands in the Spanish Media
}

\author{
Daniel Zomeño (1) and Rocío Blay-Arráez * \\ Department of Communication Sciences, School of Humanities and Social Sciences, Jaume I University, \\ 12006 Castelló de la Plana, Spain; zomeno@uji.es \\ * Correspondence: rblay@uji.es
}

Citation: Zomeño, Daniel, and Rocío Blay-Arráez. 2021. Native

Advertising-The Formats and Types of Content Most Demanded by

Brands in the Spanish Media. Journalism and Media 2: 529-544. https://doi.org/10.3390/ journalmedia2040032

Academic Editor:

Simón Peña-Fernández

Received: 5 August 2021

Accepted: 13 September 2021

Published: 22 September 2021

Publisher's Note: MDPI stays neutral with regard to jurisdictional claims in published maps and institutional affiliations.

Copyright: (c) 2021 by the authors. Licensee MDPI, Basel, Switzerland. This article is an open access article distributed under the terms and conditions of the Creative Commons Attribution (CC BY) license (https:// creativecommons.org/licenses/by/ $4.0 /)$.

\begin{abstract}
Media convergence and the incorporation of new narratives typical of the consumption habits of younger audiences in the social media environment have led to the proliferation of a wide variety of formats and types of content in the media ecosystem through which the editorial content offered to brands is being distributed. This qualitative research, using in-depth interviews with a qualified sample of branded content managers from the main Spanish media, allows us to determine the main characteristics of the native advertising demanded by advertisers. The results corroborate observations that content channelled through more sophisticated consumption experiences, using both multimedia and interactivity with a clear transmedia approach, tends to be better received by the audience and, therefore, in greater demand by brands. It also confirms that both video and social media formats have grown exponentially when it comes to providing an outlet for branded content. Based on the results obtained, a proposed classification of these products, including definitions, has been drawn up so they can be publicised to the professional world, offering the reflection and precision that their rapid development has not allowed until now.
\end{abstract}

Keywords: native advertising; formats; content typology; media convergence; media; infotainment; social media; brand

\section{Introduction}

Digitisation has emerged as the main factor reconfiguring the processes, tools and ways of dealing with both documentary and journalistic information (Salaverría 2010, p. 439). The intrusion of the Internet and social media has radically changed the use and consumption of information, opening up more interactive and collaborative journalism (Villafañe et al. 2020, p. 7) and giving rise to unprecedented globalised connectivity. This situation offers extraordinary potential for internationalised multimedia convergence, reshaping global media production, distribution and consumption (Thussu 2015, p. 4).

Henry Jenkins associates the word convergence with technological, industrial, cultural and social change, as well as with the new relationships being forged between media, audiences and media products in contemporary society. This media convergence involves the flow of content across multiple media platforms, combining languages and traditional media in an interactive format (Rigo 2016). Many forms of content convergence have occurred as a result of this technological confluence, such as connections between news websites, live broadcasts, newspapers and social media platforms. Media consumption habits are constantly changing in line with the use of new technologies, requiring new approaches to journalistic practice. This has led to profound changes in the companies that run media outlets (Hogh-Janovsky and Meier 2021; Drula 2015).

Multimedia is the factor differentiating the digital press from its printed predecessors, and digital outlets now offer their own model, in which multimediality plays a prominent role. This brings together several basic forms of information, such as text, sound, image and video, in the same environment (Guallar et al. 2010, p. 620). This digital convergence makes it increasingly necessary to pool knowledge about aspects such as information architecture, 
message production, design and visual presentation, as well as adapting messages to the technology available on different distribution platforms (Cabrera González 2009, p. 768). This makes a media product subject to the interests of users, although it also has to be adapted to the usage rules imposed by the technological medium (Drula 2015, p. 134).

New generations use the smartphone as their main source of entertainment, while they also consider it a basic element of their social lives. It is a tool for finding information and for buying and selling products and services. Social networks have become the predominant ways of accessing audiovisual content (Ramos-Méndez and Ortega-Mohedano 2017, p. 707). The increase in online video consumption has created awareness among journalists of the need to connect with an audience that constantly demands audiovisual content (Blanco and Palomo 2019, p. 1). Image resources are therefore increasingly used in text, which points to a new trend towards a visual rather than a textual approach (Cabrera González 2009, p. 782).

The media cannot continue with the one-way communication flows of the mass media era. Instead, if they want to enjoy long-term success, they must listen to their audiences and learn from them (Jenkins et al. 2013, p. 24). Consumers' power gives them the opportunity to be highly selective of the content they consume and look for only what provides value and is relevant to them (Scolari 2013). Attention has become an increasingly scarce commodity (Selva-Ruiz and Caro-Castaño 2016, p. 644), which has forced content producers to work harder as they compete with everyone else. On the Internet, social media platforms are the best settings for the attention market, and they are the easiest places for users to congregate (Giraldo-Luque and Fernández-Rovira 2020, p. 4). As a result of audience fragmentation, growing competition and media convergence, infotainment has acquired a much wider audience, as increasing numbers of people, especially the new digital generation, access their news via the internet. At a time when the media are increasingly influenced by digital networks, there is a tendency to simplify and sensationalise information (Thussu 2015, p. 4).

This paradigm shift is also reflected in advertising, which has to deal with consumers who are more critical and proactive and take a more professional attitude in their relationship with brands. Like attention, credibility is also becoming a scarce commodity (Castelló-Martínez 2018, p. 85). Retention, the development of lasting relationships with users, should be the goal, rather than simply recruiting them (Regueira Mourente 2012, p. 66). Brands seek to be useful to users and focus on creating emotional connections with consumers. Advertising can be intrusive if it fails to take into account that audiences are active and social (Papí-Gálvez 2015), so the aim is to move from push dynamics (advertisements, ads, commercials, graphics, etc.) to pull dynamics (native advertising, advergaming, apps, etc.). This encourages the emergence of formats that do not interrupt the user (Selva-Ruiz and Caro-Castaño 2016, p. 643). This context highlights the need for brands to adapt to the new content consumption habits of users, as they seek alternatives to traditional advertising that will put them in a better position to cope with the complex digital ecosystem.

Generating quality content has become a great communication opportunity for brands, which have known for some time that advertising saturation caused by intrusive, oneway approaches reduces the effectiveness of their actions. In this new situation, growing cooperation has been noted between media and brands, which have found a new approach to connecting with their audience in the form of branded content (Miotto and Payne 2019, pp. 27-28).

Within this new trend for brands to embark on content creation, the boom in native advertising is particularly noteworthy, specifically the Branded/Native Content form included by the IAB in its Native Advertising Playbook 2.0, as follows:

"Brand-paid content is published in the same editorial format used by the media outlet that hosts it. Generally, the content is produced by the publisher's own content teams. This branded content is represented on a page, hosted and served just like all editorial experiences. Scheduling, follow-up and report generation are typically supported and provided by the vendor." 
This editorial product is increasingly valued by brands, which find it to be an effective response to their need to relate to their audiences. According to a 2020 study by the Native Advertising Institute (Native Advertising Institute 2020), native advertising generated $20 \%$ of total advertising revenue for news media organisations in 2017 , and that figure is expected to be $36 \%$ by 2021.

Native advertising in media has to rely on a newspaper's ability to transfer narrative credibility from its editorial section to the branded content department (Sirrah 2019). These departments first appeared in digital native media such as BuzzFeed and The Huffington Post, which mix news and entertainment. They also adopted native advertising, becoming an economic success story mentioned by Chittum (2014). Soon, major newspapers such as the New York Times, which created the T-Brand Studio, and the Guardian, with Guardian Labs, joined in with specialist departments or business units, taking the phenomenon to a higher level of professionalisation (cited by Ferrer Conill 2016, pp. 3-9).

Communication and marketing specialists work with publishers because they want to be associated with the trust people place in the media. They want to have a brand presence that does not look like advertising to readers-something that has never been achieved before. This development has created a close relationship between brands and news publishers (Sirrah 2019), which are always looking for new ways to adapt and surprise their audience, offering interesting content that generates engagement.

\section{Materials and Methods}

The following research questions arise from the observation of the phenomenon described, which is undergoing constant transformation.

RQ1: What kind of content is the media making for brands?

RQ2: Is it possible to propose a list that would generate precise knowledge?

RQ3: Are there any common features characterising the most commonly used formats?

RQ4: Within these features, what role do audiovisual formats and social media play?

Based on these questions this qualitative research seeks to suggest a list of products and formats offered to brands by the branded content departments of the main Spanish newspapers. These are evolving at a dizzying speed, and for this reason, reflecting on them, classifying them and defining them will provide important knowledge that is easy to transfer. The objectives that have guided the study are as follows:

1. To list the different formats and types of content used by the media to create paid-for content for brands.

2. To establish the main features of the formats most in demand by brands.

3. To analyse the importance of audiovisual formats and new social media narratives in connecting with young audiences.

In order to obtain the holistic knowledge necessary for the qualitative research (Soler 2011, p. 191), it was necessary to obtain conclusions based on expert opinions (Ibáñez and Egoscozábal 2008, p. 16). To do this, it was essential to look at the professional routine of those who manage the departments we have been studying through in-depth interviews carried out in situ in the media.

The selection of the sample of branded content department managers of the main national newspapers is based on the study population obtained from the different categories of the ComScore News Ranking, specifically the data from June 2019 (Figure 1). This ranking is a reference for industry professionals as it measures media audiences on different digital platforms. 


\begin{tabular}{|c|c|c|c|c|c|c|c|c|}
\hline & \multirow{2}{*}{ Media } & \multirow{2}{*}{ 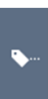 } & \multicolumn{3}{|c|}{ Total Unique VisitorsNiewers (000) } & \multicolumn{3}{|c|}{ \% Reach } \\
\hline & & & $\begin{array}{l}\text { Total Digital } \\
\text { Population }\end{array}$ & Desktop & Mobile & 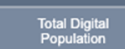 & Desktop & Mobile \\
\hline & (†) Total Internet: Total Audience & & 33.777 & 22,236 & 30.641 & $1 0 0 . 0 \longdiv { \square }$ & $1 0 0 . 0 \longdiv { 5 }$ & $1 0 0 . 0 \longdiv { \square }$ \\
\hline & News/Information & & 33,243 & 21,784 & 30,396 & $9 8 . 4 \longdiv { \square }$ & $9 8 . 0 \longdiv { \square }$ & $9 9 . 2 \longdiv { \square }$ \\
\hline 1 & †口 Vocento & $\bullet$ & 25,809 & 6,671 & 23,922 & $76.4 \square$ & $30.0 \mathrm{D}$ & 78.1 \\
\hline 2 & † Prisa & - & 25,768 & 7,733 & 23,500 & 76.3 & $34.8=$ & 76.7 \\
\hline 3 & † RCS MediaGroup - Unidad Editorial & $\bullet$ & 25,360 & 7,072 & 22,953 & $75.1 \square$ & $31.8=$ & $74.9 \square$ \\
\hline 4 & †巴 Prensa Ibérica & $\bullet$ & 24,922 & 5,612 & 23,127 & $73.8=$ & $25.2=$ & $75.5=$ \\
\hline 5 & † Grupo Godo & $\bullet$ & 23,719 & 4,440 & 22,096 & $70.2=$ & 20.0 = & 72.1 \\
\hline 6 & † Henneo & $\bullet$ & 20,732 & 3,298 & 19,044 & $61.4 \square$ & 14.81 & $62.2 \square$ \\
\hline 7 & † 巴 ELCONFIDENCIAL.COM & $\bullet$ & 15.611 & 2,852 & 13,839 & 46.2 & $12.8 \pm$ & 45.2 \\
\hline 8 & $\oplus \square$ ElEspañol Sites & $\bullet$ & 15,133 & 2,430 & 13,592 & $44.8 \square$ & 10.91 & $44.4 \square$ \\
\hline 9 & - $\square$ OKDIARIO.COM & $\bullet$ & 10,775 & 1,151 & 9,936 & $31.9 \square$ & 5.21 & 32.4= \\
\hline 10 & ๓ $\square$ Grupo Planeta Sites & $\bullet$ & 10,681 & 1,921 & 9,319 & $31.6 \square$ & 8.61 & 30.4= \\
\hline 11 & $\bullet \square$ Eldiario.es Sites & $\bullet$ & 10,045 & 1,674 & 8,834 & $29.7 \mathrm{E}$ & 7.51 & 28.8ㅁ \\
\hline 12 & † 䧃 Microsoft News & - & 9,591 & 8.863 & 2,202 & $28.4 \square$ & $39.9 \square$ & 7.21 \\
\hline 13 & $\pitchfork \square$ ElEconomista & $\bullet$ & 9,477 & 2,519 & 7,679 & $28.1 \mathrm{E}$ & 11.31 & $25.1 \square$ \\
\hline 14 & + 四 Yahoo-HuffPost News Network & $\bullet$ & 9,380 & 1,510 & 8,308 & $27.8=$ & 6.81 & 27.1프 \\
\hline 15 & † أ La Voz De Galicia & $\bullet$ & 7,940 & 909 & 7,217 & $23.5 \mathrm{~m}$ & 4.11 & 23.6高 \\
\hline 16 & † 四 Xataka & $\bullet$ & 7.627 & 2,263 & 5,948 & $22.6=$ & 10.21 & 19.4! \\
\hline 17 & $\oplus \bigoplus$ PUBLICO.ES Sites & $\bullet$ & 7,349 & 993 & 6,572 & 21.8 = & 4.51 & 21.4! \\
\hline 18 & - 曰 Periodista Digital Sites & $\bullet$ & 7,298 & 373 & 6,982 & 21.6 핌 & 1.71 & 22.8ш \\
\hline 19 & $\oplus \square$ Agencia Europa Press & $\bullet$ & 6,706 & 1,291 & 5,714 & 19.9프 & 5.81 & 18.6! \\
\hline 20 & † $\square$ Pelmorex Corp. & $\bullet$ & 6,372 & 1,557 & 5,184 & 18.9" & 7.01 & 16.911 \\
\hline 21 & †回 Grupo ADSLZone & $\bullet$ & 6,370 & 2,120 & 4,750 & 18.9 & $9.5 !$ & 15.5 \\
\hline 22 & † $\square$ Libertad Digital & $\bullet$ & 6,272 & 743 & 5,676 & $18.6 \mathrm{~m}$ & 3.31 & $18.5 \square$ \\
\hline 23 & † 回 ESdiario Sites & $\bullet$ & 5.539 & 142 & 5,397 & 16.4II & 0.61 & 17.6! \\
\hline 24 & †回 AccuWeather Sites & $\bullet$ & 5,370 & 230 & 5,165 & 15.9! & 1.01 & 16.9 |I \\
\hline 25 & UDday (Mobile ADo) & $\bullet$ & 4,570 & N/A & 4,570 & $13.5 \mathrm{~m}$ & N/A & 14.91 \\
\hline 26 & †曰 Vozpopuli.com Sites & $\bullet$ & 4,423 & 416 & 4,065 & 13.11 & 1.91 & 13.3॥ \\
\hline 27 & - $\square$ Weather Comoany. The & & 4,420 & 42 & 4,379 & 13.11 & 0.2 & $14.3 !$ \\
\hline 28 & †回 Grupo El Comercio & $\bullet$ & 4,310 & 603 & 3,809 & 12.8॥ & 2.71 & 12.41 \\
\hline 29 & - Elnacional.cat Sites & - & 4,121 & 374 & 3,798 & 12.21 & 1.71 & $12.4 !$ \\
\hline 30 & $† \square$ BBC Sites & - & 4,035 & 895 & 3,313 & 11.91 & 4.01 & 10.81 \\
\hline
\end{tabular}

Figure 1. Ranking News ComScore Top 30 News, June 2019. Reference to establish the study population.

Based on this, the need to interview experts from four types of media was determined in order to obtain knowledge of different business models, as each has different experience and has developed differently in terms of technology. To observe the phenomenon fully, we must add the experiences of the following different kinds of media:

- News/Information category. Selection of communication groups with the main traditional media titles.

- News/Information category. Selection of native digital media.

- Niche content category. Selection of vertical media for specific consumption areas.

- Millennial Media Category. Selection of media aimed at millennial audiences, with social media as their main channel.

Taking these premises, the resulting sample is one of convenience (Gaitán Moya and Raigada 1998, p. 90), based on the difficulty of personally interviewing the managers of these organisations. The media represented occupy the top positions in the various categories of the 2019 ComScore rankings. The interviewees were 16 executives representing 15 media groups or media outlets in the different categories selected (Figure 2). All were informed subjects with knowledge of the issues being researched (Gaitán Moya and Raigada 1998, p. 90), as they participate actively in the processes under study. 


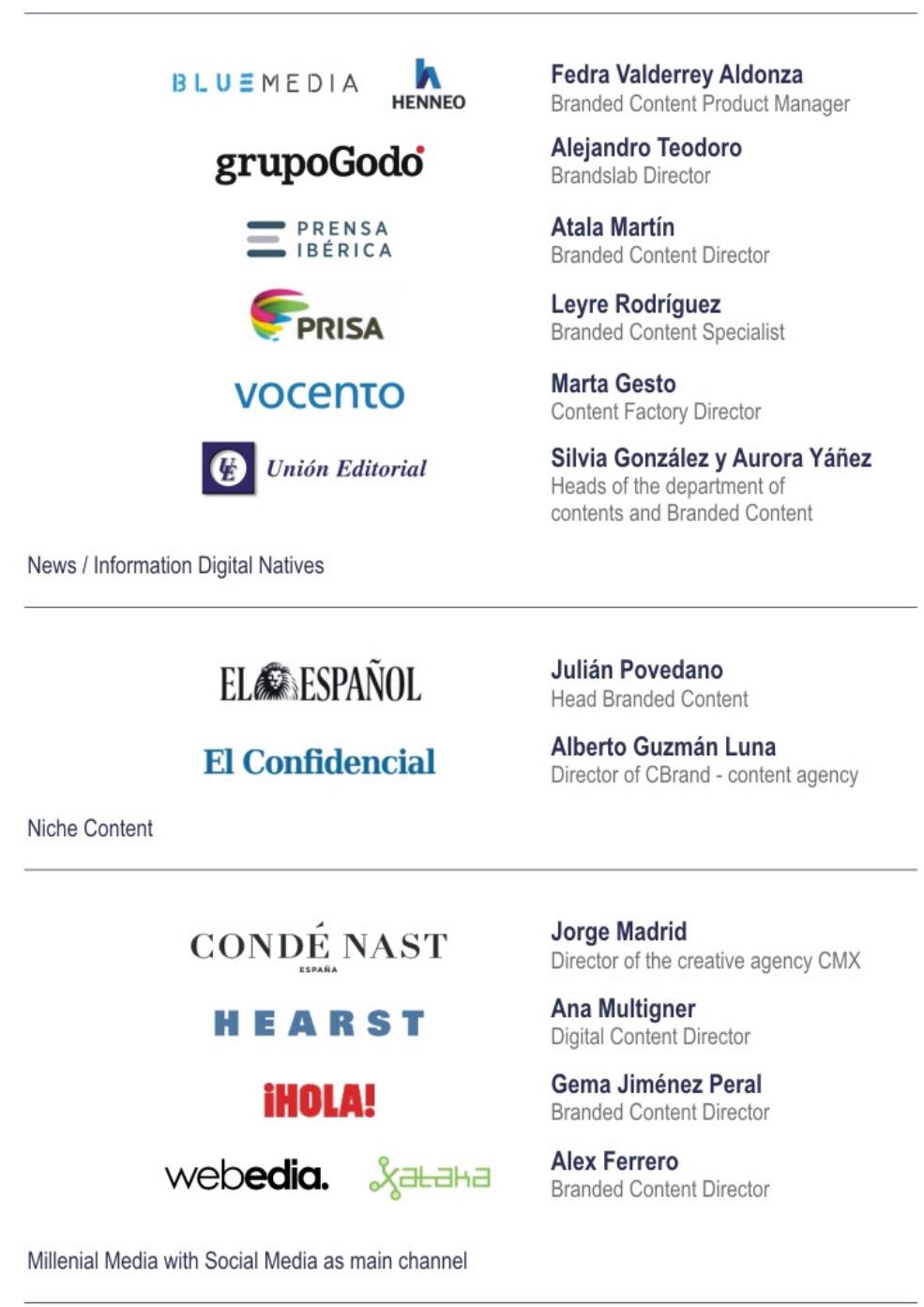

$\begin{array}{ll}\text { JOI DOWN } & \begin{array}{l}\text { Angel Fernández } \\ \text { Director }\end{array} \\ \text { PlayGround } & \begin{array}{l}\text { Davit Miró } \\ \text { Chief Revenue Officer }\end{array} \\ \text { YOROKOBU } & \begin{array}{l}\text { Marcus Hurst } \\ \text { Head of Branded Content }\end{array}\end{array}$

Figure 2. Sample of managers and groups/media interviewed.

These interviews were conducted between 20 November 2019 and 10 July 2020. 12 were face-to-face, offering us an opportunity to visit branded content departments. They each lasted an average of 120 minutes. Only three had to be carried out online because of the pandemic and lockdown. The in-depth interviews followed a structured script, with specific guidelines for formulating questions (Vilches 2011, pp. 216-19) based on the research objectives. Conducting the interview in the workplace-in the surroundings where the activity is carried out-also made it possible to draw up pre-prepared checklists based on the following objectives:

1. What are the formats used to create native pieces, and which ones are most in demand from brands? TEXTUAL ARTICLE/MULTIMEDIA ARTICLE/SOCIAL POST/SOCIAL VIDEO/ STORY/PODCAST/EVENT/INFOGRAPHIC Others? Which ones? 
2. What is the most common type of content used to create native pieces? VIDEONEWS/ DOCUMENTARY RECORD (LONGER)/TIPS/HOW TO/TRENDS/ HUMOROUS SKETCH/SOCIAL EXPERIMENT/CHALLENGE/QUIZ/ INTERVIEW/LISTICLES/ FACTS/TRAILERS/REVIEWS Others? Which ones?

Open-ended questions (Eco 1977) were also used, or, as Silverman (2014) calls them, open-ended interviews.

1. What are work processes like in the department?

2. How do other company departments take part in the creation process?

3. How can audience-building know-how be transferred from the editorial department to the $\mathrm{BC}$ department?

4. What do you consider to be the differential value of the product offered to brands by your $\mathrm{BC}$ department?

5. What part of the medium's expertise do you consider essential to attract brands?

6. How does the department capitalise on knowledge the editorial department may have about different audiences?

7. What type of research do you conduct with your target audience and how deep do your inquiries go in order to get to know them?

The results were analysed using a horizontal analysis, with a focus on the sample's set of responses to each question asked rather than the isolated opinions of each interviewee. This method follows Gaitán Moya and Raigada (1998, p. 109). The information transcribed from the interviews was segmented in accordance with categories established based on the objectives of the study, and the data were interpreted in accordance with Soler's qualitative analysis (Soler 2011). Even so, in presenting the results, some verbatim quotes are included because they are useful for illustrating general ideas.

During the fieldwork, many interviewees said they were very interested in the conclusions of the study, as the fact that these departments were set up only recently means they lack sufficiently reliable references.

Based on a classification drawn up by Chris Lake for Econsultancy known as The Periodic Table of Content Marketing and the cataloguing carried out as a result of the initial fieldwork, a panel of experts in generating content for brands was selected, made up of professionals and academics. The classification proposals and the definitions of each of the products were checked with them. The participants in the panel of experts were

1. Pepe Arenas Bueno. Content Director at PlayGround Media.

2. Antonio J. Rodriguez Soria. Creative Director at Lemon e hijos. Former Editor-inChief of Playground Media and writer.

3. Guillermo Carreras-Candi. Head of Media at Welcome to Jungle France.

4. Miriam Cacho Sol. Head of Global Content and Managing Editor at Secret Media Network.

5. José Martínez Sáez. Lecturer at Universidad CEU Cardenal Herrera.

This is a methodological approach that meets the requirements of qualitative research, such as validity (Taylor and Bogdan 1984) for data collection and precision in the analysis and summary of the results. It also shows reliability (Álvarez-Gayou and Luis 2003, pp. 3233), as the second piece of fieldwork was carried out with the panel of experts to check the conclusions of the interviews. Finally, it meets the criterion of qualitative representativeness of the sample, which is not defined by size or statistical representativeness (Wimmer and Dominick 1996, p. 67).

These two pieces of qualitative field work lead us to produce a series of critical reflections, with practical implications for the subject under study. In addition to considering the challenges faced by the media in dealing with constant technological and social change, another fundamental aim is to identify the keys to the development of these products and formats, including the funding of the media itself. 


\section{Results}

One contribution of this research is to provide a classification of the formats and content normally used by branded content departments in the Spanish media. We are aware that sometimes the terms "format" and "content" are used interchangeably, but this is a reflection of a degree of confusion detected in the sample of interviewees, as they do not differentiate between what is a format and what is a type of content. When we refer to format, we are talking about the specific features and attributes of the content host that make consuming that content a particular kind of experience. It might be an article, an image, a video, a podcast, an infographic or a social media post. Meanwhile, content type refers to the subject matter addressed and the use of value attributed to it. In most cases, the different types of content can be provided to the audience in different formats. Some content types, such as those incorporating an interactive component, give rise to a very particular narrative channelled through specific mechanisms, which is why it is common to refer to them as formats.

\subsection{Most In-Demand Formats for Native Advertising}

A wide variety of formats are currently being produced in media editorial departments, ranging from traditional journalistic articles based on the use of text and images, to all those that have been incorporated using a multimedia approach.

The results of the research show that one of these formats, which began as a result of media convergence, is being used more frequently when it comes to creating native advertising. Specifically, we are referring to the interactive format known as multimedia articles or webdocs (Sora 2015), although they are also known as longform because they are long articles dealing with a subject in some depth (Figure 3). Several of the branded content directors interviewed acknowledge that their main references when it comes to working with this type of format are the articles developed in recent years by major international newspapers through their branded content departments. T-Brand Studio is particularly outstanding in this area, with articles such as Women Inmates: Why the Male Model Doesn't Work for Netflix (Miotto and Payne 2019).

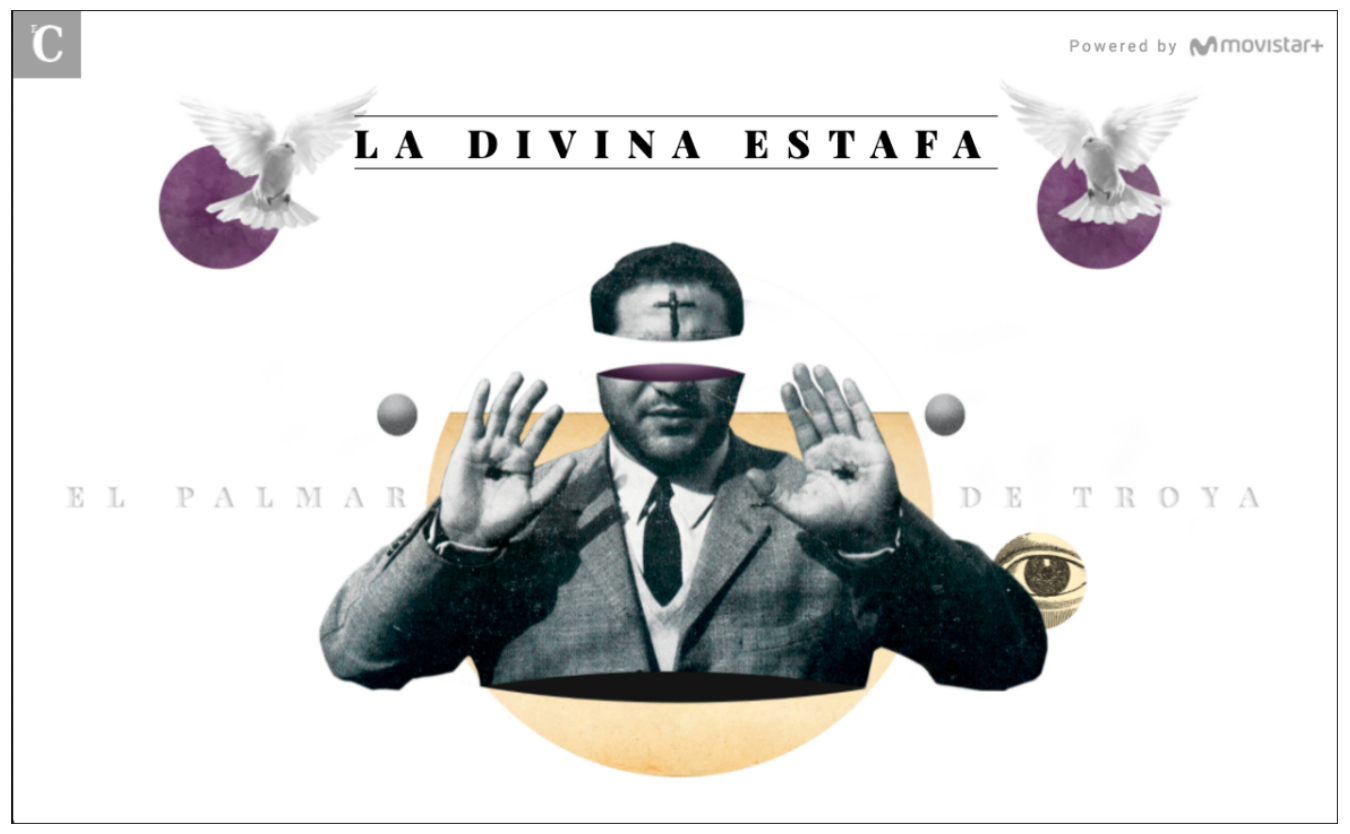

Figure 3. Native advertising action via the webdocs format for Movistar's documentary series, El Confidencial.

This format works with the traditional research article, adding an audiovisual part and an interactive component that are key to both the narrative of the piece and the user 
experience. The professionals interviewed stressed the fact that it is a high-quality product that usually involves quite high production costs. However, its ability to generate a more qualitative impact and therefore a deeper connection with viewers, increasing the time they spend on the page, makes it a very good product for brands in their quest to be included organically in editorial content.

The multimedia article is usually presented as a microsite, with attractive vertical navigation using a parallax effect. Some people therefore also refer to this format as scrollytelling, a term resulting from combining the word scroll, for browsing, and storytelling, relating to the narrative. This type of content is commonly enriched with audio, video, photo galleries, illustrations and animations, as well as interactive maps and infographics. In some cases, questionnaires are even incorporated to help gamify reading, with the application of game mechanics obtaining significant increases in audience engagement.

According to our observations, both multimedia articles and text articles tend to be used recurrently as a native advertising product so that brands can approach a specific territory hand-in-hand with the principal titles. They seek to position themselves around a series of issues normally linked to current affairs. This allows them to join in the conversation, which produces a transfer of values and reputation from the editorial section to the brand.

Another format allowing brands to approach certain territories, which has grown in recent years, is the event. Some of the groups working in this direction are Vocento and El Confidencial, which take advantage of the great convening power resulting from the great influence these media groups enjoy in the economic and political fabric of the country. Alberto Guzmán of CF brands told us about the discussion groups they usually organise for their clients, attended by spokespeople for the brands, who set out the topics they wish to address. The media call together stakeholders and experts, moderated by an in-house journalist, to discuss the topics. They provide coverage of the event, which is included for subsequent publication in the form of an article illustrated with photos and videos. According to Guzmán,

“The event is highly recommended for lobbying, especially for brands linked to areas where advertising is not allowed for legal reasons, so it is crucial to be able to have these meetings". (transcript of interview 10 December 2019)

Apart from the formats analysed, all the interviewees coincided in mentioning the standard use of image galleries, especially in the content strategies developed by media and brands linked to lifestyle and those seeking performance via e-commerce. As Anna Multigner told us, it is common to find this type of approach among the titles of groups like Elle or Squire, where the articles incorporate expandable galleries with proposed looks and valuable links.

As a result of the digitisation of journalism and the incorporation of new profiles, the media have explored the full technological potential offered by the Internet to develop formats that improve the reader's content consumption experience; thus, the use of animated infographics and interactive graphics has proliferated. These formats are often used both individually and as part of a multimedia article.

Other formats that are gradually beginning to develop in the media are apps, games and podcasts. However, one format is proving to be a true revolution for both editorial and branded content: video.

\subsection{Video and Social Media}

The profound transformation undergone in recent years by the newspaper industry, which has been forced to understand its audience's new content consumption habits, especially those of younger readers, has led the media to explore channels that necessarily involve incorporating new formats and narratives.

We are essentially referring to the video format, which, according to all interviewees, has become a key element of the product offered to brands (Carvajal and Barinagarrementeria 2019). They highlighted the fact that it has become the fastest growing format in the 
cross-media strategies being implemented, thanks to its great versatility. As Ana Multigner points out,

"Video is critical because it allows you to have different pieces for different channels. Video acts as a centrepiece, generating other formats for networks; for making a teaser; on Instagram with a short format; or something longer on YouTube. We are on many channels, and a video allows you to have a strategy with greater reach". (transcript of interview, 18 December 2019)

Another reason that has led both editorial departments and brands to strengthen their commitment to video has to do with the high percentage of traffic on mobile devices, which has led to a significant reduction in reading time. It is generally acknowledged that people are reading less and less, particularly younger audiences, so in many cases video is an interesting way to complement content (Jódar-Marín 2019). As Marta Gesto explains,

"The video part is becoming more and more important, although we have detected that this format alone does not work. The reader does not come to our titles just to watch video, but if you present the video within a content that has caught their attention, we have a very high retention rate that can reach up to 90 percent". (transcript of interview, 21 November 2019)

As well as using video to complement certain articles and improve engagement, this format multiplies its presence when it comes to capturing the attention of younger readers. The fact is that their information consumption habits, so closely linked to the different social media platforms, have led editorial departments and branded content teams to develop strategies to attract clients on social media profiles based on using video, as Jorge Madrid explained.

The vast majority of interviewees agree that, whether natively in any of the social networks or accompanying an article for a digital title, video has become one of the formats most in demand by brands when it comes to native advertising.

It is clear that in recent years there has been a real revolution in media editorial departments, which have been forced to train staff to use new formats and have had to understand the importance of developing new narratives suited to the characteristics of each platform (Martínez-Sanz and Arribas-Urrutia 2021; Villafañe et al. 2020). As Alejandro Teodoro explains,

"To understand everything that is happening with content, it is crucial to talk about the importance social media has had. We saw how a few years ago a native video format developed by Playground exploded on Facebook. These were short informative pieces, highly visual and with little text. They were very easy to consume as they were optimised for the platform. Now, Instagram is taking over, with formats such as stories, which have their gamification aspect in the form of polls. The media have to be aware that information is consumed in a certain way in each network and that the platforms' new technological developments mean they are constantly changing". (transcript of interview, 10 July 2020)

Several interviewees seemed to agree that Instagram is the leading platform for brands, particularly for some media like Yorokobu, where the creative director acknowledged that demand is extremely high and posts and stories have become the main native advertising formats they work with (Figure 4).

Ana Multigner also stressed the importance of the platform and highlighted the fact that, even within the Hearst group, products especially designed for implementation on Instagram have been developed for brands. This is the case of the Instaday format, which consists of creating a mosaic dedicated to a client on the Elle profile, with all posts on the feed used to create storytelling for the brand for that particular day.

It is clear from the research that social media has become a fundamental part of content creation. Instead of being seen as just another distribution channel operating as an amplifier, these platforms have to be considered as a medium in their own right (Campos-Freire et al. 
2016). In fact, there are many cases where advertisers do not work with branded content actions in a media title, preferring to concentrate exclusively on social media profiles.
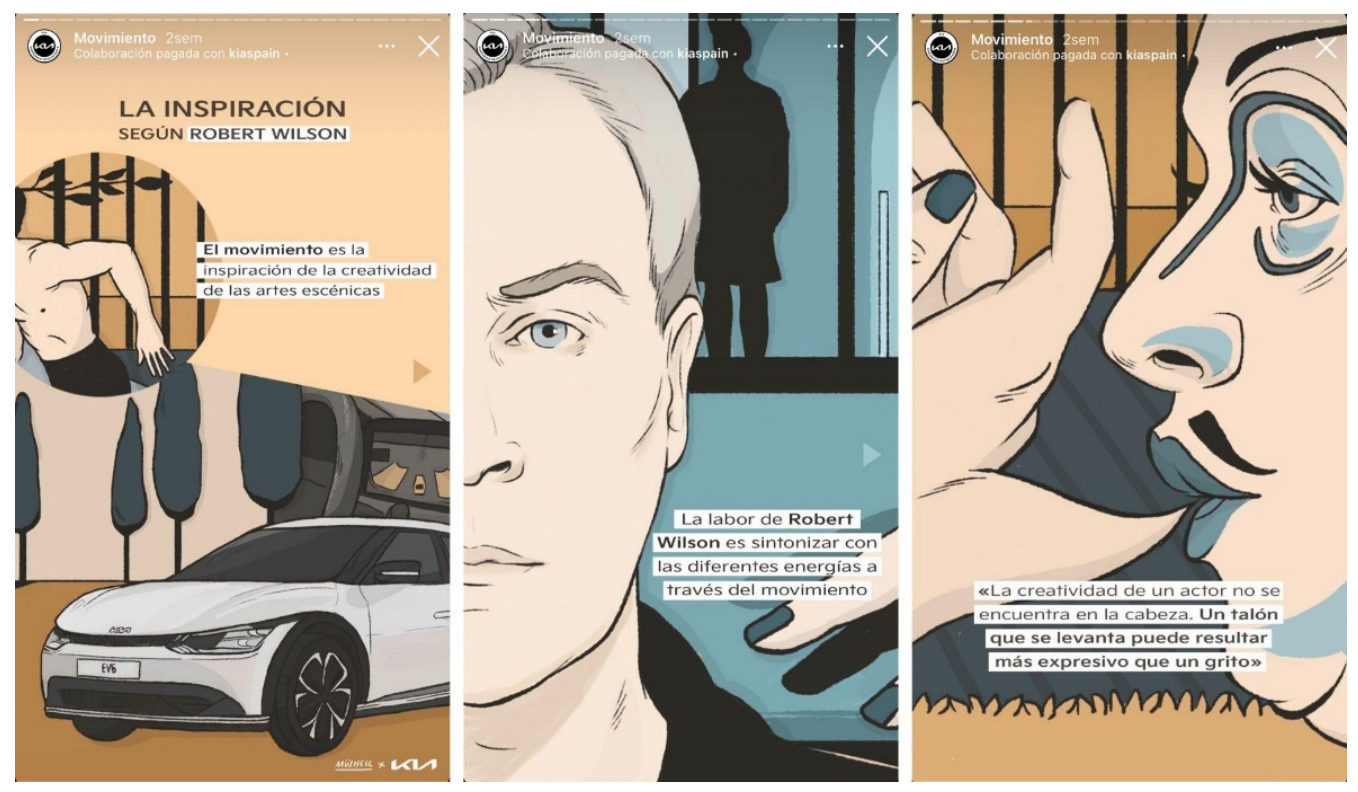

Figure 4. Native advertising action by Yorokobu magazine through its stories for KIA Spain: playwright Robert Wilson's reflections on inspiration and movement.

\subsection{Types of Content Most Commonly Used in Native Advertising}

If we consider that the main characteristic of native advertising is its ability to integrate perfectly with editorial content, maintaining the same form and function, it is clear that the topics and types of content the branded content department can use are as extensive as the content being developed by the editorial department. From our observations in this research, any content that is being offered to the audience from the editorial side is potentially valid to be used as native advertising (Watson et al. 2018). As might be expected, some topics associated with current affairs are of no interest to brands, such as politics and police reports. On the other hand, it is easy to integrate a brand into coverage of a current social issue via a multimedia article or a documentary piece.

According to several interviewees, the communications departments of large companies wanting to work on corporate social responsibility issues tend to be particularly interested in this type of content. Developing content for brands involving sustainability, innovation or the future is very common in the principal media in Spain.

Opinion platforms are also sometimes used in the same way in corporate communication. This allows CEOs to address certain topics depending on their interests and strategic schedule, also helping them to position themselves as opinion leaders. Another type of format widely used for similar strategies is the AMA (Ask Me Anything), where the audience is invited to ask the guest a series of questions so they can answer in the form of a live broadcast.

This type of content helps the client consolidate its position as an expert in a given area while providing the reader with value, as the content is of general interest.

Vertical media linked to fashion or lifestyle take a very different approach, tending to produce a type of content much more tied to infotainment. Fashion, beauty or lifestyle reports are usually linked to a character who transmits a series of values connecting with the brand through their personal storytelling. The text or video interview is also a type of content in great demand by brands when they want to link to a specific figure.

In other projects aimed at reinforcing the characteristics of a specific product, branded content departments often use a specific type of content, such as reviews. In the case of Xataka, a leading Spanish-language media specialising in technology, it is common for 
brands to come to them to publicise their products through collaborations. However, as its creative director told us, the editorial staff and experts talk about the product with total freedom, and no interference from the client is accepted.

This is not, then, a typical advertorial; it is a search for formulas, making it possible to put across the product's features without losing the editorial value of the content. Creative departments use their creativity to explore different narrative formulas that help to achieve the dual objective of responding to the brand's needs on one hand, and show the medium's commitment to the reader by offering valuable content on the other.

Much of the content used tends to come from the digital culture that has been developing in the network environment and that in some way has become a reference for media that are aware of the importance of understanding social media's communicative ecosystem.

Content types such as listicles, how-tos, hacks and FAQs (Frequently Asked Questions) usually work very well, providing readers with useful information in a simple, entertaining way. Given the media's difficulty in retaining readers' attention, the aim is to develop a type of content that is visually attractive and allows a flexible, intuitive consumption experience. This is why "explainer video" and "fact" narratives, usually relying on animated graphic resources, are so frequently used in strategies designed for social media. Another key element in understanding audiences' new way of consuming content is interactivity and gamification; the formats and content that implicitly include these, such as quizzes, tests and challenges, usually offer high levels of engagement. The never-ending search for content that will go viral is also a key element, which is why media outlets are increasingly working with content such as social experiments, due to their considerable shareable component.

In general, all media have ended up incorporating formats and types of content typical of the social media ecosystem, even historic newspapers with a more classical editorial model. But the area where there has really been a deep understanding of the importance of going beyond traditional journalistic formats to reach a new audience, based on the ability to inform using entertainment, is digital native media (Figure 5).
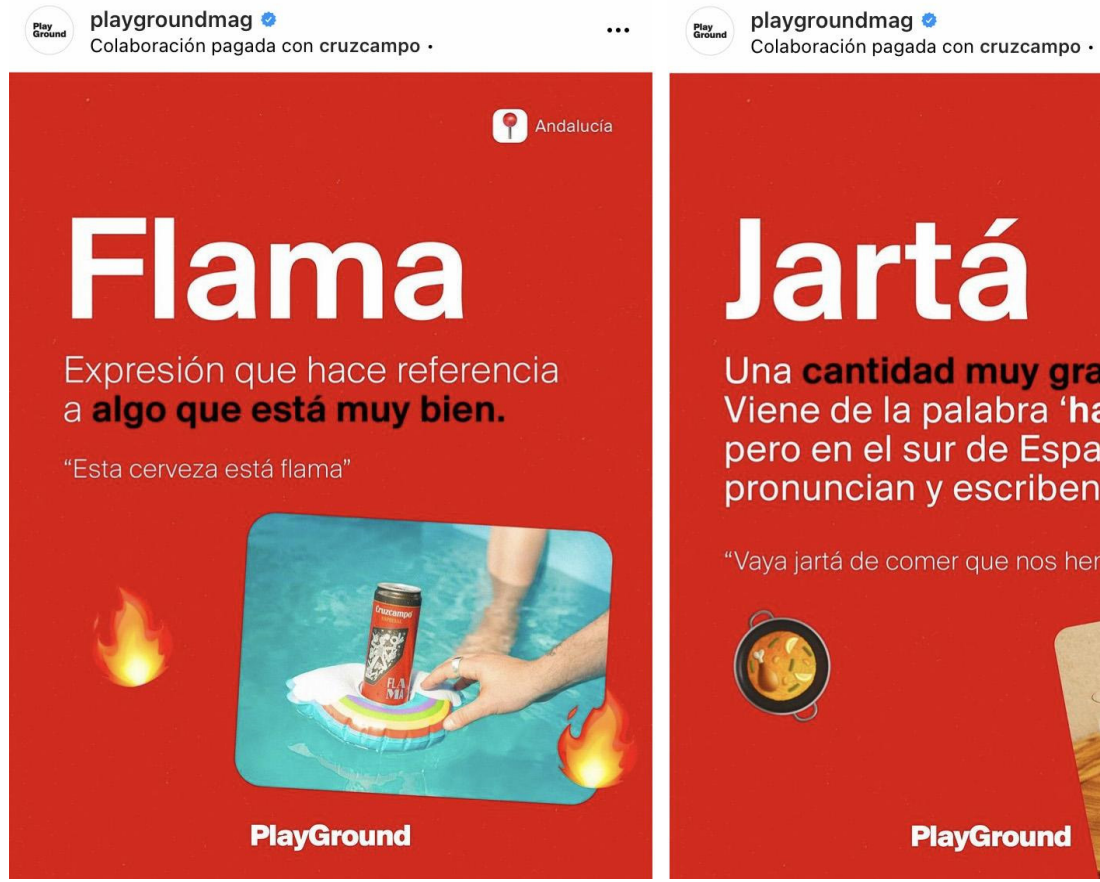

$\cdots$

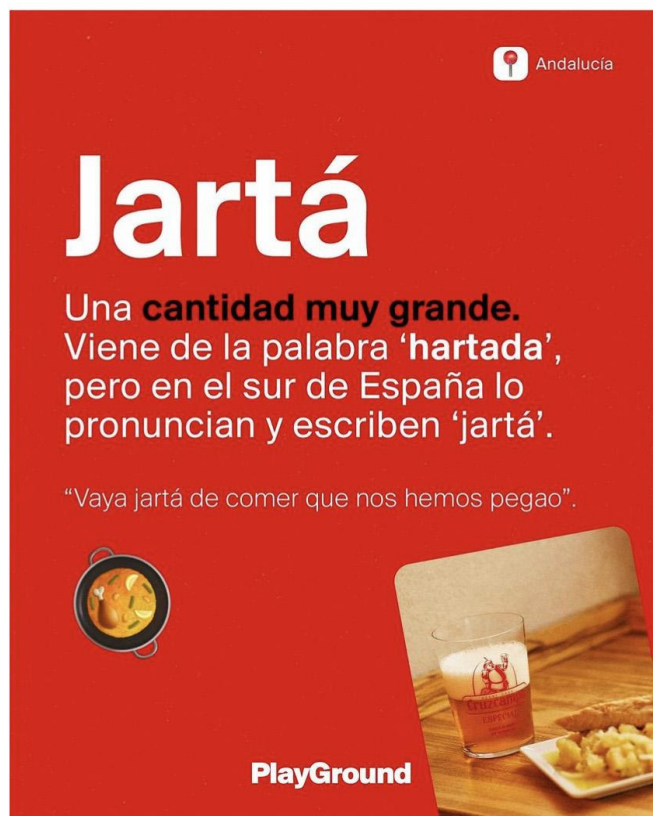

Figure 5. A social media action by Playground Magazine for Cruzcampo comprising a glossary of Andalusian slang as part of the campaign carried out by the brewers to emphasise their pride in being Andalusian. 
It is important to bear in mind that we are looking at an emerging phenomenon that tends to mix formats and narratives. The constant changes in the digital ecosystem and experiments by creators have led to great mutability in our subject of study, which makes classification work very difficult. The vast majority of the content analysed comes either from the journalistic field or the classical entertainment industry, but in this case it has been reformatted and adapted to the new narratives to make it as suitable as possible for the social media ecosystem. We therefore find certain characteristics that differentiate it from its references and gives it its own identity.

The classification resulting from this research is intended to bring a measure of order to the presentation of these products, offering definitions that will make it easy to transfer them to the professional world (Table 1). The idea is that it might be used as a guide by media departments wanting to create content for brands.

Table 1. Terminology used in the media to refer to the different formats and types of content used for editorial content and native advertising.

\begin{tabular}{|c|c|}
\hline $\begin{array}{l}\text { Ask me anything } \\
\text { (AMA) }\end{array}$ & $\begin{array}{l}\text { This is a similar type of content to interviews but with the particular feature that the questions have been } \\
\text { formulated by the audience. The two-way nature of the new channels has encouraged the emergence of } \\
\text { this type of content. }\end{array}$ \\
\hline Challenge & ontent offering a challenge to be completed by one or more participants. \\
\hline DOs and DON'Ts & $\begin{array}{l}\text { Content aimed at conveying useful information to the audience so they can carry out an action correctly. } \\
\text { Its structure is based on contrasting right and wrong actions. }\end{array}$ \\
\hline Expectation vs. Reality & $\begin{array}{l}\text { Content based on a side-by-side structure in which the expectations generated about a specific situation } \\
\text { and the real outcome are compared. Closely related to meme culture; it often involves humour. }\end{array}$ \\
\hline Facts & $\begin{array}{l}\text { Informative content aimed at highlighting a specific fact using a brief, precise text. It often relies on the } \\
\text { use of data to reinforce an empirical approach. The facts that tend to work best are those that make an } \\
\text { impact on the audience because they are unexpected. }\end{array}$ \\
\hline FAQs & $\begin{array}{l}\text { Content that includes a list of the most frequently asked questions about a particular topic and the } \\
\text { answers to them. }\end{array}$ \\
\hline Glossary & List and description of a series of terms linked to a particular area. \\
\hline Infographic & $\begin{array}{l}\text { A format characterised by combining the use of text and images to develop a theme. The visual } \\
\text { component, which can either be static or moving, is the focus of the narrative. }\end{array}$ \\
\hline Interview & $\begin{array}{l}\text { Content intended to give the audience an in-depth picture of a person or their work through their } \\
\text { answers to several questions. This is highly versatile content, which can be represented in different } \\
\text { formats and narratives. }\end{array}$ \\
\hline Listicles & $\begin{array}{l}\text { Term that comes from combining "list" with "articles". This content usually appears in the form of text } \\
\text { and it is structured as a list to make it easier to read. }\end{array}$ \\
\hline Microdoc & $\begin{array}{l}\text { Short audiovisual content intended to represent a situation from the maker's point of view. In some } \\
\text { cases, the format is less than one minute long. }\end{array}$ \\
\hline $\begin{array}{l}\text { Multimedia } \\
\text { articles/Webdocs }\end{array}$ & $\begin{array}{l}\text { Articles looking at a topic in depth, which bring together a variety of formats, such as text, image, sound, } \\
\text { video, infographics and even games, in the same piece. They require some interaction from the reader, } \\
\text { resulting in a very attractive consumption experience. }\end{array}$ \\
\hline Quiz & Playful, interactive content inviting readers to test their knowledge of a specific subject. \\
\hline Reviews & Content based on an expert's evaluation of a product or service. \\
\hline Comedy sketch & Short content in which a comic or absurd situation is recreated by actors. \\
\hline Social experiment & $\begin{array}{l}\text { Content aimed at deepening social trends based on the analysis of the behaviour of a series of people in a } \\
\text { controlled environment. Because it is consumed in social media, this type of content is more focused on } \\
\text { entertaining than on searching for academic contributions in the field of sociology. }\end{array}$ \\
\hline Social Videonews & $\begin{array}{l}\text { Informative content that fits in with social media narratives. Short audiovisual format combined with } \\
\text { text in the form of posters and images. Possibility of understanding the information without the need } \\
\text { for audio. }\end{array}$ \\
\hline Test & $\begin{array}{l}\text { Interactive content in which readers answer a series of questions about their tastes or preferences and } \\
\text { obtain a result. The full potential can only be extracted from this type of format if the result is shareable. }\end{array}$ \\
\hline
\end{tabular}


Table 1. Cont.

\begin{tabular}{cl}
\hline Tips or Hacks & $\begin{array}{l}\text { Content that incorporates a series of tips or tricks for carrying out a task or action successfully. Apart } \\
\text { from its usefulness, in some cases it seeks to publicise an amazing fact, known as the "wow fact". }\end{array}$ \\
\hline Trends & $\begin{array}{l}\text { Content that shows a series of trends and changes in a specific area. Although it can deal with any topic, } \\
\text { this type of content is usually developed in media specialising in fashion and lifestyle. }\end{array}$ \\
\hline Tutorial/How to & $\begin{array}{l}\text { Content that incorporates a series of guidelines and instructions intended to help the audience solve a } \\
\text { problem or cope with a complex task. }\end{array}$ \\
\hline Video explainer & $\begin{array}{l}\text { Informative content that deals with a specific topic quickly and simply thanks to narrative resources } \\
\text { designed to facilitate understanding. The use of graphic elements and animation is common. }\end{array}$ \\
\hline
\end{tabular}

Source: Prepared by the authors based on interviews with the different professionals in the sample and the panel of experts.

\section{Discussion}

This study, which included the most important media in Spain, found that the emergence of native advertising is undoubtedly one of the phenomena that best reflects the change in the advertising paradigm (Watson et al. 2018). Brands approach branded content departments looking for a product distinct from the classical model of advertising, which interrupts the target audience's moment of consumption. The professionals interviewed confirmed that brands are now asking to introduce their messages in the most organic way possible, integrating themselves into the medium and aiming to have the product perceived as just more editorial content (Campbell and Marks 2015). In many cases, this has led to the development of editorial products based on continuity strategies with formats that can be serialised, allowing the media to support brands seeking to achieve recurring consumption of their content by the audience. In some cases, the relationship established between brand and medium is so well established that we can find spaces specially designed to contain the native advertising created jointly and perceived as merely another category of content for the title.

When developing projects with the media, brands tend to show a predilection for formats and content types that are already established within the editorial section. These regularly obtain the best metrics, and professionals themselves refer to them as "star" formats and content. The use of successful editorial formulas also provides guarantees for the branded content department, as the audience is used to consuming this type of content. This makes it a reliable approach that will achieve the reach and objectives agreed upon with the client. When a brand insists on breaking away from the consolidated formats and requests an ad hoc approach, the result is usually not good, because the medium is moving away from its area of expertise. Thus, whenever possible, attempts are made to channel native advertising within the editorial products on the grid. The creative challenge for branded content departments is to be able to integrate the brand's communication needs into existing formats and editorial content, without conditioning them to the point where they lose value.

Although in some cases it is possible to make a contribution to designing new formats based on the native advertising, the process is usually the other way around. As several interviewees told us, the editorial products offered to brands mostly come from the editorial side. Not until the editorial staff have tested them and found that they work and have generated interest, is the decision is made to market them.

Although there is little room for experimentation and innovation, the investment made by the brand makes it possible to improve and perfect them. We can therefore conclude that most of the editorial products marketed from the business side have begun in the editorial department. The link between the two departments is therefore an essential one (Valero-Pastor and Carvajal 2019).

Among the editorial products most often used to provide an outlet for branded content, the most important are those capable of creating a high-quality user experience, based on the following factors: 
1. They bring together different formats and promote multimediality. Images, video, infographics, data display, audio or games are added to the textual part.

2. They are interactive to a considerable degree. The user can establish how the narrative develops, interacting with the different elements making up the content.

3. They incorporate gamification (the application of game mechanics). It is common to close narratives with quizzes testing the knowledge acquired, generating high levels of engagement.

4. They seek transmediality and are designed with strategies that can expand the story through the different titles and channels belonging to the media group (Peñafiel Sáiz 2016).

It is therefore important for content creators to constantly explore new forms of storytelling based on user-focused visual and interactive design (García-Avilés and Robles 2016, p. 130). This type of project usually requires high levels of development, both in terms of technology and content creation, so the high cost can be a good opportunity for incorporating brands.

Both editorial and branded content departments understand the importance of incorporating the formats and content types that tend to work natively in social media. This is short, mostly audiovisual content, with a high emotional component that helps it go viral. This is why video has become one of the most disruptive formats in the editorial departments of the media analysed (Micó and Masip 2008).

The topics and types of content used, in many cases, are a long way from more conventional journalistic formats, incorporating products from the entertainment industry that merge with the information part, giving rise to a key concept in connecting with new audiences: infotainment. In most cases, this is the key factor at the heart of the branded content created in branded content departments: content based on entertainment that provides information value, maintaining the rigour and reputation of the title (Sirrah 2019) while understanding the audience's new needs and habits.

\section{Conclusions}

The media are capitalising on their long experience in building audiences, as well as the digital transformation they have been forced to carry out, which has led them to reformulate their structures and processes to develop editorial products that meet the new communication paradigm. These disruptive changes have led the media industry to explore new business models, especially in relation to brands and traditional advertising investment. This has given rise to a new scenario in which the media, in the form of the editorial departments and creatives in charge of developing branded content, use all their editorial intelligence and expertise to serve their advertisers. This editorial intelligence is based on the ability to understand the audience's preferences and consumption habits, extracting the insights that will allow the development of content using the most suitable formats and narratives at all times. To do this, it is essential to understand the current communication ecosystem, which is deeply atomised and full of new players fighting for audiences' attention. Above all, an understanding is needed of how information consumption flows develop in these younger audiences, who show very little loyalty and whose changing habits make them extremely elusive.

In terms of the study, we must be aware that the media groups analysed are made up of different business projects. These are not limited to newspapers or magazines, as some also incorporate important radio media, where significant activities are carried out for brands. The research was designed with the intention of delving into those formats and types of content developed in the written press in particular. Nothing related to content linked to audio formats has therefore been analysed. If we consider that the new consumption habits are encouraging a significant boom in these formats, particularly those related to the world of podcasting, a future line of research opens up, providing this study with continuity. 
Another notable point regarding possible limitations of the research is that, although it works with a sample that includes the principal media in terms of metrics and size, and thus we can say that it is a significant representation of the Spanish media industry, it is somewhat more limited with respect to digital native media, focusing on distribution in social networks. These media may not be as important in the journalism industry or in terms of brand investment volumes, but they are crucial when it comes to innovation and experimentation within the field of editorial content creation. Media with great influence on younger audiences, such as Cultura Inquieta, Freeda, Brut and the leading international names like Vice and Buzzfeed, are also real laboratories for innovation, where new editorial products are constantly being explored along with new forms of collaboration with brands. If these were included in the research work, interesting new contributions could be achieved. This has been taken into account and will be addressed in future research.

Because of the speed with which new digital actors appear and the consolidation of new technological platforms and consumption habits among younger audiences, especially generation $Z$, it is not difficult to foresee that the results obtained will require updating to reflect new trends in the emergence of new formats and types of content. From the new narratives generated on platforms such as Tik Tok by the audience through usergenerated content, to brands' new strategies in their quest to integrate themselves into the Twitch livestreams of the main content generators, these phenomena will need to be studied for their ability to anticipate new trends to be incorporated by the media into their creative dynamics.

Some formats and types of content will remain; others will adapt and be adapted to the technological advances of the platform that hosts them, shaping new narratives; while others will entirely disappear to make way for new content arising from innovation and experimentation. This is, therefore, an open line of research that will require constant observation of both the phenomenon of native advertising and the development of editorial content, as they follow parallel paths.

Author Contributions: Conceptualization, D.Z. and R.B.-A.; methodology, D.Z. and R.B.-A.; investigation, D.Z. and R.B.-A.; writing—original draft preparation, D.Z. and R.B.-A.; writing-review and editing, D.Z. and R.B.-A. All authors have read and agreed to the published version of the manuscript.

Funding: This research received no external funding.

Institutional Review Board Statement: Not applicable.

Informed Consent Statement: Not applicable.

Conflicts of Interest: The authors declare no conflict of interest.

\section{References}

Álvarez-Gayou, Jurgenson, and Juan Luis. 2003. Cómo Hacer una Investigación Cualitativa, Fundamentos y Metodología. Mexico City: Paidós.

Blanco, Sonia, and Bella Palomo. 2019. Desencuentro de los periodistas con YouTube. El Profesional de la Información 28. [CrossRef]

Cabrera González, Ma Ángeles. 2009. El diseño de la prensa digital española en el contexto de la convergencia tecnológica. La identidad visual del ciberperiodismo. RLCS, Revista Latina de Comunicación Social 64: 766-86.

Campbell, Colin, and Lawrence J. Marks. 2015. Good native advertising isn't a secret. Business Horizons 58: 599-606. [CrossRef]

Campos-Freire, Francisco, José Rúas-Araújo, Xosé López-García, and Valentín-Alejandro Martínez-Fernández. 2016. Impacto de las redes sociales en el periodismo. El Profesional de la Información 25: 449-57. [CrossRef]

Carvajal, Miguel, and Iker Barinagarrementeria. 2019. Contenido de marca en diarios españoles: Concepto, organización y retos de los periodistas implicados. Blanquerna School of Communication and International Relations 44: 137-52.

Castelló-Martínez, A. 2018. La dimensión creativa del concepto de insight aplicado a la publicidad. Empatizando con el target de la comunicación persuasiva. In Creatividad en Publicidad. Del Impacto al Comparto. Edited by Francisco García García, Victoria Tur-Viñes, Isidoro Arroyo Almaraz and Luis Rodrigo Martín. Madrid: Dykinson, pp. 83-114.

Chittum, Ryan. 2014. Native Ads Grow Up. The New York Times Gets the Controversial Format Right. Available online: http: //www.cjr.org/the_audit/native_ads_grow_up.php (accessed on 8 September 2021).

Drula, Georgeta. 2015. Formas de la convergencia de medios y contenidos multimedia: Una perspectiva rumana. Revista Comunicar 44: 131-40. [CrossRef]

Eco, Umberto. 1977. Cómo se Hace una Tesis, Técnicas y Procedimientos de Investigación, Estudio y Escritura. Barcelona: Gedisa Editorial. 
Ferrer Conill, Raul. 2016. Camouflaging Church as State. Journalism Studies 17: 904-14. [CrossRef]

Gaitán Moya, Juan-Antonio, and José-Luis Piñuel Raigada. 1998. Técnicas de Investigación en Comunicación Social, Elaboración y Registro de Datos. Madrid: Síntesis.

García-Avilés, Jose A., and Félix Robles. 2016. Géneros periodísticos en los formatos visuales de Twitter: Una propuesta de tipología. Textual E Visual Media 9: 101-32.

Giraldo-Luque, Santiago, and Cristina Fernández-Rovira. 2020. Redes sociales y consumo digital en jóvenes universitarios: Economía de la atención y oligopolios de la comunicación en el siglo XXI. Profesional de la Información 29. [CrossRef]

Guallar, Javier, Cristòfol Rovira, and Sara Ruiz. 2010. Multimedialidad en la prensa digital. Elementos multimedia y sistemas de recuperación en los principales diarios digitales españoles. El Profesional de la Información 19: 620-29. [CrossRef]

Hogh-Janovsky, Isabell, and Klaus Meier. 2021. Journalism Innovation Labs 2.0 in Media Organisations: A Motor for Transformation and Constant Learning. Journalism and Media 2: 361-78. [CrossRef]

Ibáñez, Carmen Lafuente, and Ainhoa Marín Egoscozábal. 2008. Metodologías de la investigación en las ciencias sociales: Fases, fuentes y selección de técnicas. Revista Escuela De Administración De Negocios 64: 5-18. [CrossRef]

Jenkins, Henry, Sam Ford, and Joshua Green. 2013. Spreadable Media: Creating Value and Meaning in a Networked Culture. New York and London: New York University Press.

Jódar-Marín, Juan Ángel. 2019. Los nuevos formatos audiovisuales en los cibermedios: Del reportaje televisivo al videonews. Communication E Society 32: 63-75.

Martínez-Sanz, Raquel, and Amaia Arribas-Urrutia. 2021. El rol de las redes sociales para futuros periodistas. Manejo, uso y comportamiento de estudiantes y profesores universitarios de Ecuador. Cuadernos.Info 49: 146-65. [CrossRef]

Micó, Josep-Lluís, and Pere Masip Masip. 2008. Recursos multimedia en los cibermedios españoles: Análisis del uso del vídeo en El País. com, El Mundo. es, La Vanguardia. es y Libertad Digital. Trípodos 23: 89-105.

Miotto, Giorgia, and Gregory Payne. 2019. Branded content: Una nueva apuesta para el New York Times. adComunica. Revista Científica de Estrategias, Tendencias e Innovación en Comunicación 17: 23-39. [CrossRef]

Native Advertising Institute. 2020. The Ultimate Native ADS Guide. Available online: https:/ /blog.nativeadvertisinginstitute.com/ native-advertising-ultimate-guide (accessed on 21 May 2021).

Papí-Gálvez, Natalia. 2015. Nuevos medios y empresas innovadoras. El caso de las agencias de medios. El Profesional de la Información 24: 301-9. [CrossRef]

Peñafiel Sáiz, Carmen. 2016. Reinvención del periodismo en el ecosistema digital y narrativas transmedia. adComunica. Revista Científica de Estrategias, Tendencias e Innovación en Comunicación 12: 163-82. [CrossRef]

Ramos-Méndez, Diego, and Félix Ortega-Mohedano. 2017. La revolución en los hábitos de uso y consumo de vídeo en teléfonos inteligentes entre usuarios millennials, la encrucijada revelada. Revista Latina de Comunicación Social 72: 704-18. [CrossRef]

Regueira Mourente, Francisco Javier. 2012. El Contenido como Herramienta Eficaz de Comunicación de Marca. Análisis teórico y Empírico. Ph.D. thesis, Universidad Rey Juan Carlos, Madrid, Spain.

Rigo, Marisa Natalia. 2016. Convergencia mediática: Nuevas formas de pensar a los medios de comunicación. Paper presented at XVIII Congreso REDCOM, Universidad Nacional de La Plata, Buenos Aires, Argentina, September 6-9. Available online: http:/ / sedici.unlp.edu.ar/handle/10915/74134 (accessed on 8 September 2021).

Salaverría, Ramón. 2010. Prensa digital y bibliotecas (Ernest Abadal y Javier Guallar). Reseña de libro. El Profesional de la Información 19: 439-40. [CrossRef]

Scolari, Carlos. 2013. Narrativas Transmedia: Cuando Todos los Medios Cuentan. Barcelona: Grupo Planeta.

Selva-Ruiz, David, and Lucía Caro-Castaño. 2016. Uso de datos en creatividad publicitaria: El caso de Art, Copy \& Code de Google. El Profesional de la Información 25: 642-51. [CrossRef]

Silverman, David. 2014. Interpreting Qualitative Data. Methods for Analyzing Talk, Text and Interaction. London: SAGE.

Sirrah, Ava. 2019. Guide to Native Advertising. Available online: https:/ /www.cjr.org/tow_center_reports/native-ads.php (accessed on 14 May 2021).

Soler, Pere. 2011. La investigación cualitativa. Un enfoque integrador en Vilches. In La Investigación en Comunicación. Métodos y Técnicas de la era Digital. Edited by Loreno Vilches. Barcelona: Gedisa, pp. 189-236.

Sora, Carles. 2015. Etapas, factores de transformación y modelo de análisis del nuevo audiovisual interactivo online. El Profesional de la Información 24: 424-31. [CrossRef]

Taylor, Steve J., and Robert Bogdan. 1984. Introducción a los Métodos Cualitativos de Investigación. Buenos Aires: Paidós.

Thussu, Daya Kishan. 2015. Infotainment. In International Encyclopedia of Political Communication, 1st ed. Edited by Gianpietro Mazzoleni. Hoboken: John Wiley \& Sons, pp. 1-9. [CrossRef]

Valero-Pastor, José María, and Miguel Carvajal. 2019. Transferencia de conocimiento para la innovación en las organizaciones periodísticas. Estudio de casos españoles. Revista Latina de Comunicación Social 74: 1154-72. [CrossRef]

Vilches, Lorenzo. 2011. La Investigación en Comunicación. Métodos y Técnicas en la era Digital. Barcelona: Gedisa Editorial.

Villafañe, Justo, Yolanda Ortiz-de-Guinea-Ayala, and José-Luis Martín-Sáez. 2020. Reputación de los medios de comunicación españoles. El Profesional de la Información 29. [CrossRef]

Watson, Sara M., Emily J. Bell, Nushin Rashidian, and Abigail Hartstone. 2018. The Future of Advertising and Publishing. Columbia: Columbia University Academic Commons. [CrossRef]

Wimmer, Roger D., and Joseph R. Dominick. 1996. La Investigación Científica de los Medios de Comunicación. Barcelona: Editorial Bosch. 